\title{
Exploring Conflict Management Using Qualitative Approach
}

\author{
Zaleha Yazid \\ School of Management, Faculty of Economics and Management, National University of Malaysia
}

\begin{abstract}
This paper focuses on qualitative methods in researching the area of conflict management, specifically in Self-Managed Project Team (SMPT). The research aims to explore the evolvement of conflict management strategies in SMPT as this type of team is given the responsibility to solve problems and make decision by themselves. The inductive approach will overcome the limitation of quantitative method in management research as one of its objectives is to explain the different elements of the explored social system and their interconnection. Hence, it aims at the contextual understanding of social behavior rather than extensive measurement. This paper also includes the research activities in details such as the data collection methods which involved semi-structured interviews and weekly telephone interviews. The findings of the research proposed that conflict management strategies in SMPT changes over time from confrontation and cooperative style towards avoidance due to the issues of reputation and the deadline.
\end{abstract}

\begin{abstract}
Abstrak: Makalah ini fokus pada metode penelitian kualitatif dalam bidang manajemen konflik, khususnya di SelfManaged Project Team (SMPT). Penelitian ini bertujuan untuk mengeksplorasi keterlibatan tim strategi manajemen konflik di SMPT yang diberikan tanggung jawab untuk memecabkan masalah dan membuat keputusan sendiri. Pendekatan induk:tif akan mengatasi keterbatasan metode kuantitatif dalam penelitian bidang manajemen yang salah satu tujuannya adalab untuk menjelaskan unsur-unsuryang berbeda dari sistem sosial yang dieksplorasi dan interkoneksinya. Oleb karena itu, hal tersebut bertujuan untuk pemahaman kontekstual perilaku sosial daripada pengukuran yang luas. Makalab ini juga mencakup kegiatan penelitian secara rinci seperti metode pengumpulan data yang melibatkan wawancara semi-terstruktur dan wawancara telepon mingguan. Temuan dari penelitian yang diusulkan adalab babwa strategi manajemen konflik di SMPT berubah dari waktu ke waktu dari konfrontasi dan gaya kooperatif menuju kepada pengbindaran (tindakan menghindari/pencegahan) yang disebabkan oleh reputasi dan tenggat waktu.
\end{abstract}

Keywords: conflict management; inductive approach; qualitative methods; self-managed project team (SMPT)

JEL classification: D74, M19

* Corresponding author's e-mail: leyha@ukm.edu.my 


\section{Introduction}

Conflict management strategies have been discussed in the literature which underlines different ways of handling conflict in teams and organizations. The various conflict management strategies and lack of consensus in the wider literature have resulted in the recognition of different styles of conflict management strategies as highlighted by researchers (Chen et al. 2005; De Dreu 2006; and Lovelace et al. 2001). Traditionally, conflict handling strategy has been viewed as a way which should encourage and creatively channel conflict into effective problem solving (Deutsch 1973). However, recent researchers have adopted a different perspective as conflict handling is seen not only for effective problem solving, but also aims for effective management as well as a way of meeting the time frame of any particular project (Chen et al. 2005; De Dreu and Van Vianen 2001). It is claimed that conflict management strategies being applied influences other decision-making activities within a team (Kuhn and Poole 2000).

This study focuses on exploring conflict management in SMPT. SMPT is a team which consists of interdependent individuals who have accepted responsibility for a group task as well as being responsible for the decision making and problem solving within the team (Cohen and Ledford 1994), also known as a bossless team, which describes the structure of a team that has no leader (Barry 1991). De Leon (2001) observes that members of selfmanaging teams are reluctant to deal with conflict and often ignore or avoid it. An ethnographic study by Barker (1993) observes how turnover and the introduction of new team members disrupts otherwise stable teams, leading to increased conflict and a redesign of control systems within the teams.
That is an example of SMPT reducing individual autonomy and interdependence as a response to conflict. Such transformation of SMPT members, when faced with conflicts, shows how conflict and its management play an important role in the social dynamics of this particular type of team. Therefore, a conflict management strategy is considered as an important factor which influences the dynamics of the SMPT. It does play an important role in teams as it provides further understanding of how members within teams relate with each other (Levine and Thompson 1996). A number of studies focus on the importance, benefits and weaknesses of conflicts in organizations (Barker et al. 1988, Chen et al. 2005) and much is known about the causes and effects of conflict in teams (Jehn and Bendersky 2003). However, what remains unknown is whether the existing studies can explain the process of conflict management in project teams, particularly self-managing ones.

In addressing the concern, the researcher's selected paradigm should be appropriate for the nature of the research problem, the assumptions regarding methodology as well as the nature of the study require the researcher to explain and understand what is unique and particular about conflict management strategies and the development of the project teams. Hence, the research will be based on the presumption that conflict is something that cannot be avoided in teamwork and will be personally experienced by each of the team members. As conflict is intangible, it is necessary for the researcher to be directly in contact with the person involved in the research context in order to understand them. This enables the researcher to appreciate the respondent's feelings, attitudes, meanings, values, and beliefs and leads to understanding of the team members' be- 
havior and their activities (Denzin and Lincoln 2005)

With regard to this, this research adopted the paradigm of interpretivism as the findings of the research will be drawn from the respondents' experience and interpretation (Bryman 2004). Under this paradigm, social reality is viewed as subjective and regarded as the product of processes by which social actors negotiate the meanings for actions and situations and this is produced through social interaction (Bryman 2004; and Carson et al. 2001). Interpretivism is known as being appropriate to effectively investigate the complex nature of reality as understanding of the world can only be achieved through knowledge as perceived by individuals (Carson et al. 2001, Bryman 2004). This suggests that any interpretivist research should attempt to understand and explore problems within a specific context (Carson et al. 2001) and in the case of this research, the context of the SMPT.

This approach argues that in order to describe a phenomenon, it is not sufficient to rely exclusively on objective measures and quantifiable observation such as theory testing using deductive logic to reason (EasterbySmith et al. 2011; Ticehurst and Veal 2000; Cavana et al. 2001). Instead "the subjective meanings and social context of an individual's words or deeds must be examined more deeply" (Rubin and Babbie 2001). This is to ensure that an in-depth understanding of the phenomenon is captured, thus any interviews conducted from the settings can be used to inform other settings (Cooper and Schindler 2001).

As the subject of the research, the exploration of conflict management within SMPT, is of a dynamic nature which consists of people activities, constant interpretation is necessary throughout the research process. In order to capture the event of conflict within the project team, it is identified that the usage of language is essential as it is also regarded as one of the important aspects when studying social life (Hardy 1994).

\section{Methods -Qualitative Approach}

Methodology selection is influenced by the ontology and epistemology that inform the study (Zalan and Lewis 2004) as well as the objective(s) of the study and the nature of the research problems. Qualitative methodology is described as the non-numerical examination and interpretation of observations, for the purpose of discovering underlying meanings and patterns of relationship (Babbie 1988). The methods derive from multiple disciplines and from diverse traditions. Those traditions are ethnography, case study, and grounded theory, and they utilize particular methods such as interviews, focus groups and observations (Crabtree and Miller 1999). As this study intends to induce ideas for theory building, qualitative methodology is most suited (Orlikowski and Baroudi 1991).

Qualitative research involves methods which allow a researcher to "focus on the interpretation" as well as "to examine the way people think and act" (Ezzy 2001). It is also suggested that an interpretation of the interview is subjective because it may be affected by the place, time, people, and circumstances of the interview (Ezzy 2001). For example, when the interview is conducted by someone else in a different setting, the response might be different. However, what is more important and makes research more rigorous is not what is said, but rather how the inter- 
pretation is generated, and how the research findings reflect the particular social context (Ezzy 2001).

In the areas of conflict management and SMPT development, researchers have used various approaches in conducting their research. For example, in the study of intragroup conflict, a quantitative approach is being used by several authors, for example, Barker et al (1988); Jehn and Mannix (2001); and Langfred (2007). However, when the study deals with human beings and processes such as team development and conflict management, Hammersley (1992) argues that qualitative research is the most appropriate. However, a thorough analysis of this particular process will require the researchers to use personal interpretation that results from the presence or participation in the process being examined. This is in line with the view that the study of conflict must be conducted as a dynamic process, rather than static as suggested by early conflict theorists (Deutsch 1969).

Lye et al. (1997) suggest that, in order to provide rich explanations, the research method must not attempt to ignore or simplify the complexities of the context that control the phenomena under investigation, but should instead, clarify them. Thus, qualitative data collected in a processual manner to a specific context are more suitable because they can be a source of well-grounded explanations of processes occurring in their local context (Miles et al 2013). Therefore, in this research, a processual approach is being applied during the data collection.

For this research, the researcher followed the basic guidelines of inductive qualitative research. Hence, the researcher was looking for open and unclear issues that emerged from a basic literature review leading to more gen- eral research concerns expressed by the research objective (Auerbach and Silverstein 2003) which, in this case, is to explore the effect of conflict and its management strategies towards the social dynamics of the SMPT. The objective guided the data collection and analysis process and was explicitly refined during analysis. Ultimately, this led to the development of emergent hypotheses. These emergent hypotheses were then compared with the existing literature (Eisenhardt 1989). This process involves looking into what is similar to and what contradicts the existing literature on the specific subject as well and understanding the reasons of the similarities and differences (Eisenhardt 1989).

\section{Research Strategy - Case Study}

As mentioned earlier, the main aim of this study is to explore the evolvement of conflict management in SMPT. Hence, a research strategy that allows the aim to be achieved is required, which is the case study approach (Yin 2003). The case study approach is known as the most suitable in answering how and why research questions rather than what or how much (Hartley 2004; and Yin 2003).

A case study is an exploration of a case (or multiple cases) over time through detailed, in-depth data collection involving multiple sources of information rich in context (Creswell 1998). Case studies are known to be appropriate in research which requires detailed understanding of social or organizational processes due to the richness of data collected in context (Hartley 2004). It can be used for various purposes such as providing descriptions, testing theory or generating 
theory (Eisenhardt 1989). It is also useful in exploring new and emerging processes or behaviors as well as enabling researchers to understand everyday practices and their meanings to those involved. The techniques being used allow trust to develop between the researcher and the organization members over a period of time that will allow some information to be obtained which would not be given to the researcher if it was a one-off interview (Hartley 2004).

The use of multiple case studies in this research followed the principles of data collection established by Eisenhardt (1989) and Yin (2003). Multiple sources of evidence are used, which include in-depth semi-structured interviews (Silverman 2007), consisting of face-to-face interviews and telephone interviews which are applied in the data collection, with an addition of the organizations' documents.

\section{Research Activities - Cases Selection Method}

Selection of cases is one of the important decisions that have to be made by a researcher prior to data collection. Several different types of sampling have been discussed, such as theoretical sampling and purposeful sampling (Eisenhardt 1989, Yin 2003). With regard to this research where an inductive approach is being adopted, cases are selected based on theoretical sampling instead of random sampling as suggested by Eisenhardt (1989).

Theoretical sampling underlines the importance for cases to be selected for theoretical exploration rather than statistical hypothesis-testing purposes (Glaser and Strauss 1967). Theoretical sampling provides flexibility during the research process (Glaser and
Strauss 1967; and Strauss and Corbin 1998) and it involves sampling to test, elaborate and refine a category, their relationship and their interrelationships. This could involve changing the interview questions as the study progresses.

Regarding the selection of the right sample size, Eisenhardt (1991) and Stake (1995) point out that how much is known and how much new information can be gained from any further participants are much more important. The sample size cannot be established in advance as each research participant has the potential opportunity to develop and refine theory (Auerbach and Silverstein 2003).

In this study, the data collection process was conducted in two phases. The first phase consists of data collected in two organizations in Malaysia, ITCo and BioTechCo. Two projects were selected from each organization as case studies. Semi-structured faceto-face interviews were conducted for three months with the respondents, consisting of the management and the people involved in at least one of the projects conducted by the organizations. The data gathered from the face-to-face interviews provide the contextual background for the study. This then continues with the agreement from the respondents to participate in a weekly telephone interview, to be held for another three months, in order for the researcher to gather processual data for the study.

The sample selections are based on the context of the study which is on SMPT in knowledge-intensive firms. As this type of organization consist of knowledge workers whose ideas and new discoveries are the most valuable assets for organizations, all projects selected in the study involved creating and developing solutions or products for internal 
and external purposes and the group of people chosen to be the team members must possess necessary knowledge and skills in completing each of the projects.

In the study, the respondents are knowledge workers involved in current projects and who are members of the organization. They are individuals who have an employment relationship with the organization in the sense of being full-time, permanent staff as well as individuals who have an employment relationship with the firm, either temporary or contingent. There is no involvement of individuals from outside the organization.

As the research proceeded, it was found that further investigation was required to challenge the initial findings from the four cases. Therefore, the second phase of the data collection was initiated. Two cases from one organization in Malaysia were selected. Faceto-face interviews were conducted for one month and weekly telephone interviews were conducted for three months, similar to the previous data collection duration, in order to maintain similarity with the longitudinal data collection in the first phase.

In Eisenhardt (1991) and Stake's (1995) opinion, the researcher has to keep recruiting and interviewing respondents until no new data is produced that adds new insights to theory construction or no new information is learned about the research topic. This procedure is called 'theoretical sampling' (Glaser and Strauss 1967) and ultimately determines the sample size of the study (Auerbach and Silverstein 2003). This approach was followed throughout the interview phase of this study which involved iterative steps in data collection and analysis in order to determine a certain level of saturation (Eisenhardt 1991), that is, following interviews became informed by analytic questions and hypotheses about data relationships drawn from previous interviews (Strauss 1987).

\section{Research Domain}

The project teams participating in this research consist of three small and medium sized knowledge intensive firms in Malaysia. The organizations entirely depend on projects as their main activities. One firm is ITCo, which is from the Information Technology industry specifically focusing on multimedia development; another, BioTechCo, is involved in the Biotechnology industry which focuses on life sciences research using bioinformatics solutions; and the third firm is Herbal Co, which focuses on research and development of herbal and organic product ranges. To protect the participating project teams and organizations' anonymity, pseudonyms are provided.

Several characteristics will be highlighted to differentiate the SMPT chosen for this study as compared to other types of project team. The project teams selected in this research are real project teams working on specific projects in organizations. The team members have interrelated tasks within the team (Cohen and Bailey 1997) which require them to work closely and become dependent on one another, they also have a variety of abilities (Cohen and Ledford 1994) - their own set of skills and expertise in their own field- which is important for performing each of their tasks.

The team members are also given responsibilities and freedom in decision making and managing their tasks (Cohen and Ledford 1994). This involves any decision making processes regarding their project and in dealing with people inside and outside the team. Each of the project teams has no identifiable formal leader within the team but 
there are managers of the organizations who exist outside the team. There is no hierarchical form for each of the project team structures, as the team is dominated by horizontal forms of peer-to-peer relations within the team.

\section{Data Collection}

The study comprises evidence collected in two phases consisting of face-to-face semistructured interviews and weekly telephone interviews in each phase. The first phase of the data collection was conducted for 6 months which began with 3 months of faceto-face interviews and another 3 months of weekly telephone interviews with team members and the managements from 4 projects in 2 small and medium sized organization in Malaysia, known as ITCo and BiotechCo.

As the research progressed, the second phase of data collection set out to challenge the initial findings from the first phase. The second phase was conducted for four months which began with one month of face-to-face interviews and three months of weekly telephone interviews with the respondents. The respondents for the second phase consisted of the management and team members of 2 projects from one small and medium KIF in Malaysia, known as HerbalCo.

For both phases of the data collection, the data gathered from the weekly telephone interviews are the main data being used in this research which provide longitudinal, processual data of conflict and its management strategy in each of the project teams and the face-to-face interviews provide contextual data for further understanding of the processual data.

There are three reasons for adopting the semi-structured interview, the first being, compared to the structured interview method, it allows for more knowledge generation. Thus, the use of a semi-structured approach allows for unexpected developments that may arise. Secondly, the dynamic nature of project teams is different from one project to another and from one organization to another. Thus, the use of semi-structured interviews allows further questions to be asked based on the unique situation surrounding a particular project team. Finally, compared to the unstructured interview style, the semi-structured approach is more likely to facilitate cross case comparison.

During the data collection process, additional documents were also provided by the organizations involved. Documents are written data sources which include published and unpublished documents, company reports, and newspaper articles, and they can be used both in quantitative and qualitative approaches to research (Schindler and Cooper 2001). In this research, documents such as memos and notes on the activities involved in the projects were provided by the interviewees, thereby helping the researcher to further understand the nature of the projects and the organizations.

\section{Face-to-Face Semi-Structured Interviews}

Semi-structured interviews are a flexible and adaptive research technique that can be modified to suit the needs of different groups of participants (King 1994). It is an intermediate step in a continuous spectrum of possible interviewing characteristics ranging from structured interviews in a more quantitative domain to completely unstructured in-depth interviews in a more qualitative approach (Bryman 2004). In this sense, semistructured interviews leverage the strengths of both structured and unstructured interview methods. It offers sufficient flexibility 
to approach different respondents differently while still covering the same areas of data collection. However, the weaknesses of the semi-structured interviews are that they are time consuming, in addition the researcher will need to prevent the urge to show agreement or disagreement to the respondent to avoid bias (Klenke 2008).

Particularly for this research, face-toface semi-structured interviews were conducted at the beginning of the two phases of the data collection process to provide the contextual data in exploring the event of conflict and its management strategies in all the six cases. Initially, e-mails were sent to several organizations in order to gain access for the data collection purposes. Some organizations replied and several rejected the requests by providing their own reasons; as a consequence, and with the assistance of a network of personal contacts from the researcher's previous work experience, more organizations were approached. As highlighted by Johland Renganathan (2010), academic research may not be considered valuable by organizations and they are usually sceptical about the role of outsiders researching their organization due to confidentiality.

However, three of the knowledge intensive firms in Malaysia agreed to grant the researcher access to their organizations and the agreement was recorded via e-mails sent by the CEOs of each organization. Following their approvals, the researcher liaised with the 'gatekeeper' introduced by the CEO in order to brief them on the nature of the study and the type of projects in which she was interested. Permission was granted to the researcher on conducting interviews with the employees in the organizations. The information sheet, together with the consent form, was distributed to the potential participants. The issue of data confidentiality was ex- plained in the information sheet. Those who agreed to participate in the research returned the signed consent form to the researcher.

In the first phase, the researcher went to Malaysia and a set of 45 face-to-face semistructured interviews were conducted with two organizations: ITCo and BioTechCo. Some of the respondents were interviewed more than once due to time constraints and as they were working on two different projects. The respondents from both organizations were interviewed respectively at an agreed time after they had provided consent to be included in the study. The face-to-face interviews required few visits to each company and each of the interviews lasted between one to two hours.

In BioTechCo, a set of 20 face-to-face interviews was conducted with 16 respondents who included the CEO, directors, managers as well as the project team members who consisted of bioinformaticians and scientists. Nine of the interviewees were involved in both Project A and Project B. The researcher was introduced to the people in the organizations by the CEOs, therefore making it easy for the researcher to personally contact them and arrange interviews at a mutually convenient time and place. Besides conducting the interviews during office hours, some people wanted to be interviewed during their lunch break while some outside office hours. The interviews were arranged on specific days with agreement from the respondents so that the researcher was able to best utilize each of the visits to the organization.

In ITCo, 25 face-to-face interviews were conducted with 12 respondents including the $\mathrm{CEO}$, managers and the project team members. The project team members consisted of the animators, multimedia executives and the modelers. Five of the respondents were work- 
ing on both Project C and Project D. A list of names of the people involved in the projects was provided to the researcher by the manager. During each of the visits to ITCo, a meeting room was provided to be used by the researcher to conduct the interviews. A clerk assisted the researcher in arranging the interviews with all of the respondents.

On reflection, the educational background of the researcher, which is in the field of information technology, provides familiarity with some of the projects being conducted in the organizations. This makes it easy for the researcher to understand the selected projects. Meanwhile, in the second phase, a set of 15 face-to-face interviews were conducted with one organization, HerbalCo. 13 respondents were involved in the interview consisting of the factory manager and the project teams' members who are the scientists, quality controller and the research and development (R\&D) executives. During the first visit, the factory manager agreed to arrange a suitable time for the interview sessions with all the respondents thus enabling the researcher to conduct several interviews in each visit.

The face-to-face semi-structured interviews cover a broad range of information and discuss the participants' meanings and perceptions on conflict and conflict management strategies that they currently implement during their project as well as their relationship inside and outside their project team. It was clarified and ascertained before the interviewing process that the individuals to be interviewed were those who were involved in at least one project in the company. The multiple perspectives from the participants contribute to the insightful approach on understanding the project that each company is involved in.
Prior to the interview session, the researcher studied the company's background using each of the organization's websites and company profiles. In addition, an interview guide was developed consisting of a list of questions to be covered which were structured around the research themes in the study. This was done to ensure that the interview format was consistent across the cases. The interview guide was necessary in guiding the interviews to be more focused rather than too general (Bryman 2004). Before the interview guide was finalized, it was tested for clarity on several fellow doctoral students. This procedure ensured that the interview questions would be clear to the interviewees selected as the respondents for the research. At the beginning of the face-to-face interview sessions, the researcher reviewed the purpose of the study with the individuals involved, then moved into the interview questions. The interview sessions were all digitally recorded and then transcribed and translated where necessary.

\section{Weekly Telephone Semi- Structured Interview-Diary Study}

In order to capture processual data for the research, weekly telephone interviews were conducted. This enables a direct and frequent recording of the respondents' experiences and events every week which is adopted from the diary study approach (Unsworth and Clegg 2004). Diary study design enables the researcher to capture the current and spontaneous events and daily life experiences of the respondents (Bolger et al. 2003). Diary study design is the most appropriate method of capturing changes over time or any processual phenomena of either individual or group setting (Unsworth and Clegg 2004). 
Particularly in this research, the researcher takes the record as a diary rather than the participant. As the diary is recorded by the researcher, this increases the willingness of the respondent to participate in the longitudinal study. Compared to the respondent's self-recorded diary, this will not require high commitment and dedication from the respondents in order to record their weekly work activities by themselves which will be time consuming and there is also tendency for the participant to skip recording on certain weeks due to being forgetful or just unwilling to update their own diary at any point in time (Bolger et al. 2003). This might be due to the participant's work and personal life commitment. Therefore, by having the researcher recording the weekly diary via telephone interview, the researcher will be able to remind the participant about the weekly phone calls and not be too intrusive. Additionally, during the interview, further clarification can be gathered from the respondent regarding any issue which is unclear from the previous week.

The data collection process continued with weekly telephone interviews with some of the previous respondents during the faceto-face interviews which consisted of management personnel as well as those who were involved in project teams. There was no difficulty faced by the researcher in gaining and maintaining access to the three organizations for weekly telephone interviews as permission was given by each organization for the researcher to further conduct the interviews. Additionally, the relationship between the researcher and the respondents had already developed as a result of the face-to-face interviews that were conducted at the early stage of the data collection. This facilitated the process of getting back in touch with the respondents for them to agree to be further interviewed via telephone.
In order not to interfere with the tight work commitment of the respondents, both the researcher and the respondents reached agreement that the telephone interviews should be conducted on a weekly basis for a duration of twelve weeks. This enabled the researcher to capture the processual nature of the project team social dynamics with regard to conflict and conflict management strategies. The 12 week duration was decided upon considering the permission of access given by the organizations, as well as considering the planned time length for the whole research process.

During the weekly telephone interviews process, trust begins to develop between the respondents and the researcher. Respondents become more open with the researcher and they are willing to share more information such as in depth stories of their experiences and feelings in their project team which offers some useful information for the research. The process of interpreting the interviews is conducted by considering different sides of stories from each of the respondents from the same projects which provides various versions of reality for the researcher to consider. The approach that was used allowed respondents to tell their stories without any evaluation and interference from the researcher. The semistructured interview questions being asked allow the respondents to express the truth about the reality of their experiences in each of their projects and this requires the researcher to maintain systematic inquiry as well as demonstrating integrity while conducting the interviews.

In the firstphase of the weekly telephone interviews, 10 respondents from BioTechCo agreed to participate and eight of them were involved in both Project A and Project B. As for ITCo, eight respondents agreed to participate and three of them were involved in both 
Project C and Project D. However, one of the respondents involved in project $\mathrm{D}$ withdrew from the study on Week 3 due to personal reasons.

Meanwhile, in the second phase, a total of eight respondents from HerbalCo agreed to participate in the weekly telephone interviews and six were involved in both Project $\mathrm{E}$ and Project F. Each of the weekly telephone interviews lasted about 15 to $30 \mathrm{~min}$ utes and all were digitally recorded.

The telephone interviews were conducted using the hands free function on the telephone which allows the telephone conversation to be heard using the speaker on the telephone and then recorded using a digital voice recorder upon the respondents' agreement. The interviews were held in a secluded room which was equipped with the hands free telephone and digital recorder to protect confidentiality of information as the loudspeaker function was being used.

Since the weekly interview was to explore the process of conflict and conflict management strategies in project teams in a processual manner, questions were asked to describe how the week had been and on any interesting events that happened throughout the week. The same interview questions were asked throughout the 12 week duration of the weekly telephone interviews.

The digitally recorded data were carefully listened to repeatedly; transcriptions were typed and notes (researcher reflections with regard to issues being researched) were also written. Although the language during the interview was a mix of both Malay and English language, it was predominantly Malay. Therefore, the transcriptions were then translated by the researcher into English. The researcher took careful steps to ensure the quality and originality of the meaning was maintained.

\section{Data Analysis}

In this study, the data were analyzed in two stages: within-case analysis and crosscases analysis. This took place after the transcription and translation of both the face-toface and telephone interviews had been undertaken after the interviews. Within-case analysis is an in-depth study of each individual site. According to Strauss (1987), the process involves the following: Each case has to be analyzed separately. The central idea is to become familiar with every single case on its own to identify unique patterns which, for this study include the team's social dynamics, before generalizing patterns across cases. To avoid being overwhelmed by the data sets, the within-case analyses were focused around the already identified research objectives dealing with conflict and its handling strategies. General conclusions regarding all cases could then be drawn. With cross-case techniques it is more likely to discover some novel findings that are incorporated in the data by looking at it in many different ways (Eisenhardt 1989).

The within-case analysis entailed sifting through all the data gathered from the weekly telephone interviews, documents and face-to-face interviews. As the weekly interviews provided processual data, the interviews were reviewed sentence by sentence in order to identify the occurrence of different types of conflict within the project team and the way each conflict is managed. Meanwhile, the face-to-face interviews and additional company documentations were also scanned for the purpose of further understanding on the context and technicality of 
each of the project. The data were then sorted.

The idea was to allow the most significant information to emerge from all the data gathered during the interview sessions, while reducing its volume. Generally, from the transcription, direct quotations and a particular experience or incident describing the interviewee's experience, especially related to conflict evolvement and management in the project team were coded under several tracks. The key material relevant to the research was coded into various categories according to the research themes (Yin 2003). The quotations and particular experience or incidents provided by the respondents assisted the researcher's interpretation and assessment of each case.

The next step of the analysis consisted of cross-case analysis in the search for patterns of events. To begin with, a table consisting of the project duration, the types of conflict and the dynamics of the team members with regard to conflict management strategy was created. The cases in the table were then compared to each other and linkages between different types of conflict and conflict management strategies were highlighted. The similarities and differences among them were noted for further analysis. The techniques of pattern-matching and explanationbuilding were used. This approach was aided by a variety of analytical tools applied within and across the cases, as suggested by Miles et al. (2013). For example, Time-Ordered Matrices, and Event Listings were used to identify and chronicle the event of conflicts and conflict management strategies that was implemented as well as the project team dynamics.

In most instances, direct quotes from case informants were used, as they were be- lieved to best reflect the phenomena under investigation. Given the processual perspective of the research, all analysis was conducted chronologically as the basic sequence of cause/effect should not be in a reversed form. Further, a major area of the literature, based on the self-managing team, focuses on sequential stages, thus chronological analysis was relevant. This approach is also supported by Gersick (1988) as appropriate to the study of the social dynamics on project teams.

\section{Findings}

It was found that conflict management strategies being implemented by the team members are: cooperative, confrontation and avoidance. The people involved tend to cooperate when conflict occurs as it helps them in achieving the team's objective which is by cooperating with one another as it helps them to solve the conflict and then continue focusing on their assigned task. On the other hand, confrontation is being implemented whenever the project team is having conflict specifically with outside project team. The team members confront those involved in order to solve the conflict.

Avoidance is another conflict management strategy being implemented by the project team during task conflict and it occurs whenever the conflict is more intense as time goes by. The people involved in the conflict tend to avoid dealing or communicating with each other and not directly deal with conflict. This then leads the project team to seek assistance from the management. Even though they are given the responsibility to solve their own conflict, as conflicts get more intense and time goes by, assistance is needed from the management. 
Below, evidence is presented from the projects on each of the conflict handling strategies being implemented in the event of task conflict.

\section{Conflict Management Strategy: Confrontation}

"Everyone in the team was concerned about this matter. So we decided to confront the people there so that it won't delay our work. We had planned for our tasks. We don't want that to get delayed just because of the people there." (MrZ, Scientist,Wk4, Project B)

'It's a relieve that we are able to talk directly with her on this matter. We wouldn't want to work under pressure every day and we wouldn't be happy receiving negative complaints about our work every day as if we are not able to conduct our task. The way she behaves before really annoyed most of us." (MrH, Scientist, Wk.5, ProjectE)

"I'm glad that we are able to have a discussion with her regarding the matter. She claimed that she's doing her job but at the same time it is good that we suggested that she could do it in a better way, as in a better approach of giving us feedback. She accepted this and apologizes to us." (MrS, Scientist,Wk.5, ProjectE)

"That's what we are doing now. We wanted them to know that there are things that the management needs to improve. It is not easy to directly talk with them as we are like a big family, but how could we do our work if things like this are distracting us" (MrK, Storyboard Artist, Wk3, Project C)

\section{Conflict Management Strategy: Cooperative}

"We are a group of professional people, it's well-balanced, each of them will share their experience and we will talk to each other what we will do and we will try to finish our work. It's a team work, not an individual work. So, everything we do, it is as a team." (MrT, Bioinformatician, Wk3, ProjectA)

"We know that it can be avoided but still, it happened. So, what we did was we discuss...we discuss until we've found the right solution and that everyone is happy." (MrT, Bioinformatician, Wk.5, ProjectA)

"We believe what we did is the best thing. We can't afford to waste our energy and time waiting for the chemical stuff. The management might be expecting us to do the same thing too. So, our meeting was held and all of us agreed on our new task schedule and we will be working on something else while waiting for the delivery." (MrM, Scientist, Wk.5, ProjectF)

"We had an urgent meeting. We brainstorm on how we could make things better and trying to get ourselves agree on the good suggestions. Believe me, it was not an easy thing to do!" (MrB, ReD Executive, Wkes, ProjectF)

\section{Conflict Management Strategy: Avoidance}

"I can feel the difference now. It's no longer the same as before. The team members are all doing their own task and when there are some issues, we won't talk to each other to solve it but we directly talk to the team leader. I don't think this is good for us." (MrZ, Scientist, Wk7, ProjectB)

"Due to the stressful nature of doing our tasks and the short time period to finish each task, sometimes we did misunderstand each other but now, we just keep it to ourselves. I guess performing and finishing the task is much more important than how we feel." (Miss An, Scientist, Wk7, Project B)

"It is very difficult you know...I would rather keep quiet than say something. These people are just there to point finger if anything goes wrong." (MrZ, Scientist, Wk 11, ProjectB)

"It's quite disturbing when we are not communicating well. We need to discuss about our tasks 
but someone else is not giving their feedback." (MrRg, Bioinformatician, Wk6, ProjectB)

"I don't want to give any opinion. No one will agree and it looks like everyone is busy with their own task and we seldom communicate with each other unless it is very important. It is very quiet in the lab nowadays." (MrK, Scientist, Wk8, ProjectE)

'It's no longer the same working environment as before. We are so quiet and I can see people coming in and out of MrSh office. I guess we would rather communicate with him rather than among ourselves now. The unhappy feeling that we are experiencing changed the team. I hope the management can belp us to improve the situation. It is getting worse. How can we work with minimal interaction as we are in a team." (MrM, Scientist, Wk8, Project E)

It is evident that cooperation and confrontation are the conflict management strategies being chosen during conflict in most of the projects in the earlier weeks of the data collection. As time passes by, avoidance is evident when the conflict becomes more intense.

\section{Discussions}

Conflict management strategies have been widely discussed in the previous literature, including conflict avoidance, confrontation, cooperative and competitive styles which provide insight into different ways of managing conflicts in teams and organizations (Chen et al. 2005; De Dreu and Weingart 2003; Tjosvold and Sun 2002). The strategies implemented by teams are claimed to be consistent throughout a project as a team will continuously adopt the same style when conflict occurs (Speakman and Ryals 2010). However, this was not evident in this study which revealed that, over time, the team changes its conflict management style with the influence of the different types of conflicts that occur as well as when the conflict occurs for the project's duration. Three different patterns of conflict handling strategies are identified: cooperative, confrontation and avoidance.

The finding is consistent with Vliert's (1997) suggestion that organizations are not limited to only choosing one conflict management strategy but typically use a combination of different strategies while dealing with conflict. The changes of conflict management styles are identified as being related to several factors throughout a project. It was discovered that the concern for project deadline and individual reputation influence the choices for conflict management strategies by SMPT.

Concern for the project deadline results in ignoring conflict handling; therefore, the team members decide to focus on their task rather than solving conflict which leads to them avoiding the conflict. Individual reputation is another factor which changes the approach towards conflict management strategies as team members are concerned with their reputation and showing others that they are doing the right things. This leads towards changing of the conflict handling approach to ensure that their reputation is being taken care of.

The conflict avoidance which was evident in this study has been highlighted in the literature as appropriate for collectivist societies where relationships are highly valued (Leung 1997). Malaysians are described as 'collectivist' that is their identity is not determined by individual characteristics, but instead by the collectivity or group to which the person belongs (Abdullah 1996; and Mellahi and Wood 2004). Adding to this, in 
the Malaysian context, it is very common for people not to discuss sensitive issues with each other as a result of cultural preference (Merriam and Mohamad 2000). This means that the people will always try not to hurt others' feelings. It could be assumed that this action is due to them wanting to preserve the relationship with others. This explains why Malaysians avoid making others feel embarrassed or humiliated in public.

It was found that cooperative and confrontation strategies are being implemented by SMPT at certain points during task conflicts whereas for the relationship conflict, avoidance is being implemented all the time by the team members. This suggests that SMPT are culturally bound due to the approaches taken by the team members regarding conflict situations. This is in contrast to the individualistic culture of the Western country where people prefer to confront directly during conflict and regard conflict avoidance as being selfish and not helping to solve any problems (Amason 1996; and Lovelace et al. 2001). Conflict avoidance, as revealed in the study, is evidently the result of the need to maintain harmony as well as close relationships amongst team members. This shows that in the society, cultural issues which involve individual reputation affect the social dynamics of SMPT in dealing with conflict.

The findings of the study lead to the following propositions:

P1: Conflict management strategies in SMPT changes over time due to concern of reputation and the deadline.
P1a: The deadline leads to changes of conflict management strategies in SMPT.

\section{P1b: Importance of reputation leads to changes of conflict management strategies in SMPT.
P1c: Conflict avoidance occurs when team mem- bers are concerned with their reputation and the deadline.}

\section{Conclusion}

In this study, the evolvement of conflict management strategies in SMPT was explored. One important direction for future research is to conduct a longitudinal study involving a multiple data collection procedure to explore the social dynamics of SMPT as to how they are affected by conflict and its management strategies throughout a complete lifecycle of a project. As projects need various timeframes in order to be completed, a longer duration of data collection is needed. Researchers could incorporate this method to shed more light on the effect of conflict and conflict management strategy on SMPT and its impacts on the success or failure of the project over time.

In conclusion, this study has enriched the discussion in the current conflict management and SMPT literature. Using an inductive approach, the outcome is the proposition on the transformation of conflict management strategies. The study suggests that the SMPTs transform into an avoidance approach during conflict as time goes by. In any event, conflict and its management strategies are fostered or hindered by factors such as the approaching deadline as well as individual reputation. 


\section{Acknowledgement}

The authors acknowledge the financial support from the following research grant in conducting this study: The UKM GGPM Grant, code GGPM-2012-045, titled "Exploring the Effects of Conflict towards the Social Dynamics of Project Teams in Malaysia."

\section{References}

Abdullah, A. 1996. Going Glocal: Cultural Dimensions in Malaysian Management. Kuala Lumpur, Malaysia: Malaysian Institute of Management.

Amason, A. 1996. Distinguishing the effect of functional and dysfunctional conflict on strategic decision making: Resolving a paradox for top management. Academy of Management Journal39 (1): 123-148.

Auerbach, C. F., and L. B. Silverstein. 2003. Qualitative Data: An Introduction to Coding and Analysis. New York: New York University Press.

Babbie, E. R. 1988. The Practice of Social Research (4 ${ }^{\text {th }}$ ed.). Belmont, CA: Wadsworth.

Barker, J. R. 1993. Tightening the iron cage: Concertive control in self-managing teams. Administrative Science Quarterly 38 (3) (Sept.): 408-437

Barker, J., D. Tjosvold, and I. R. Andrews. 1988. Conflict approaches of effective and ineffective project managers: A field study in a matrix organization. Journal of Management Studies 25 (2): 167-178.

Barry, D. 1991. Managing the bossless team: Lessons in distributed leadership. Organizational Dynamics 20 (1): $31-47$.

Bolger, N., A. Davis, and E. Rafaeli. 2003. Diary methods: Capturing life as it is lived. Annual Reviews in Psychology 54: 579-616.

Bryman, A. 2004. Social Research Method. Oxford: Oxford University Press.

Carson, D. J., A. Gilmore, C. Perry, and K. Gronhaug. 2001. Qualitative Marketing Research. London: SAGE Publication.

Cavana, R., B. L. Delahaye, and U. Sekaran. 2001. Applied Business Research: Qualitative and Quantitative Methods. Queensland, Australia: John Wiley \& Sons.

Chen, G., C. Liu, and D. Tjosvold. 2005. Conflict management for effective top management teams and innovation in China. Journal of Management Studies 42 (2): 277-300.

Cohen, S. G., and D. E. Bailey. 1997. What makes teams work: Group effectiveness research from the shop floor to the executive suite. Journal of Management 23 (3): 239-290.

Cohen, S. G., and G. E. Ledford. 1994. The effectiveness of self managing teams: A quasi experiment. Human Relations 47 (1): 13-43.

Cooper, D. R., and P. S. Schindler. 2001. Business Research Methods. Boston, MA: McGraw-Hill.

Crabtree, B., and W. Miller. 1999. Doing Qualitative Research (2 $2^{\text {nd }}$ ed.). London: Sage.

Creswell, J. W. 1998. Qualitative Inquiry and Research Design. London: Sage.

De Dreu, C. K. W., and A. E. M. Van Vianen. 2001. Managing relationship conflict and the effectiveness of organizational team. Journal of Organizational Behavior 22 (3): 309-328. 
De Dreu, C. K. W. 2006. When too little or too much hurts: Evidence for a curvilinear relationship between task conflict and innovation in teams. Journal of Management no. 32 (1):83-107. doi: 10.1177/ 0149206305277795.

De Leon, L. 2001. Accountability for individual behaviours in self-managing teams. Organizational Development Joumal 19 (4): 7-19.

Denzin, N. K., and Y. S. Lincoln. 2005. Handbook of Qualitative Research ( ${ }^{\text {nd }}$ ed.). Thousand Oaks CA: Sage Publications.

Deutsch, M. 1969. Conflicts: Productive and destructive. Journal of Social Issues 25: 7-41.

Deutsch, M. . 1973. Conflicts: Productive and destructive. In Conflict Resolution Through Communication. New York: Harper \& Row.

Easterby-Smith, M., R. Thorpe, and P. Jackson. 2011. Management Research (4 ${ }^{\text {th }}$ ed.). London: Sage.

Eisenhardt, K. M. 1989. Building theories from case study research. Academy of Management Review 14 (4): 532-550.

Eisenhardt, K. M. 1991. Better stories and better constructs: The case for rigor and comparative logic. Academy of Management Review 16: 620-627.

Ezzy, D. 2001. Are qualitative methods misunderstood? Australian and New Zealand Journal of Public Health 25 (4): 294-297.

Gersick, C. J. G. 1988. Time and transition in work teams: Toward a new model of group development. Academy of Management Journal 31 (1): 9-41.

Glaser, B., and A. Strauss. 1967. The Discovery of Grounded Theory: Strategies for Qualitative Research. New York: Aldine de Gruyter.

Hammersley, M. 1992. What's Wrong with Ethnography? London: Routledge.

Hardy, C. . 1994. Underorganized interorganizational domains: The case of refugee systems." Journal of Applied Behavioral Sciences 30 (3): 278-296.

Hartley, J. 2004. Case Study Research. In C. Cassell and G. Symon (Edt.), Essential Guide to Qualitative Methods in Organizational Research. UK: Sage.

Jehn, K. A., and E. A. Mannix. 2001. The dynamic nature of conflict: A longitudinal study of intragroup conflict and group performance. Academy of Management Journal 44 (2): 238-251.

Jehn, K., and C. Bendersky. 2003. Intragroup conflict in organizations: A contingency perspective on the conflict-outcome relationship. In B. M. Staw and R. M Kramer (Edt.), Research in Organizational Behaviour: 187-242. Greenwich CT: JAI Press.

Johl, S, K., and S. Renganathan. 2010. Strategies for gaining access in doing fieldwork: Reflection of two researchers. The Electronic Journal of Business Research Methods 8 (1): 42 -50.

King, N. 1994. The Qualitative research interview. In C. Cassell and G. Symon (Edt.), Qualitative Methods in Organisational Researcb: 14-36. London: Sage.

Klenke, K. 2008. Qualitative Research in the Study of Leadership. Bingley, United Kingdom: Emerald Group Publishing Limited.

Kuhn, T., and M. S. Poole. 2000. Do conflict management styles Affect group decision-making? Evidence from a longitudinal field study. Human Communication Research 26: 558-590. 
Langfred, C. W. 2007. The downside of self-management: A longitudinal study of the effects of conflict on trust, autonomy, and task interdependence in self-managing teams. Academy of Management Journal 50 (4): 885-900.

Leung, K. 1997. Negotiation and Reward Allocations Across Cultures. San Francisco: Jossey-Bass.

Levine, J. M. , and L. Thompson. 1996. Intragroup Conflict. In E. T. Higgins and A. W> Kluglanski (Edt.), Social Psychology: Handbook of Basic Principle: 745-776. New York: Guildford.

Lovelace, K., D. Shapiro, and L. Weingart. 2001. Maximizing cross-functional new product teams' innovativeness and constraint adherence: A conflict communications perspective. Academy of Management Journal 44: 779-793.

Lye, J., H. Perera, and A. Rahman. 1997. Grounded Theory: A Theory Discovery Method for Accounting Research. Melbourne: University of Melbourne.

Mellahi, K., and G. T. Wood. 2004. HRM in Malaysia. In Parwan S. Budhwar (Edt.), Managing Human Resources in Asia Pacific. Oxon: Routledge.

Merriam, S. B., and M. Mohamad. 2000. How cultural values shape learning in older adulthood: The case of malaysia. Adult Education Quarterly 51 (1): 45-63.

Miles, M. B., A. M. Huberman, and J. Saldaña. 2013. Qualitative Data Analysis: A Methods Sourcebook: SAGE Publications.

Orlikowski, W. J., and J. J Baroudi. 1991. Studying information technology in organizations: research approaches and assumptions. Information Systems Research 2 (1): 1-8.

Rubin, A., and E.R. Babbie. 2001. Research Methods for Social Work (4 ${ }^{\text {th }}$ ed.). Belmont, CA: Brooks/Cole.

Schindler, D. R., and P. S. Cooper. 2001. Business Research Methods (7 ${ }^{\text {th }}$ ed.). New York: McGraw-Hill.

Silverman, D. 2007. Interpreting Qualitative Data: Methods for Analyzing Talk, Text and Interaction ( ( $\left.^{\text {th }} \mathrm{ed}.\right)$. London: Sage Publications.

Stake, R. E. 1995. The Art of Case Study Research. Thousand Oaks, CA: Sage.

Strauss, A. L. 1987. Qualitative Analysisfor Social Scientists. Cambridge: Press Syndicate of the University of Cambridge.

Strauss, A. L., and J. M. Corbin. 1998. Basics of Qualitative Research: Techniques and Procedures for Developing Grounded Theory Sage Publications.

Ticehurst, G., and A. Veal. 2000. Business Research Methods. Malaysia: Pearson Education Australia.

Unsworth, K, and C. Clegg. 2004. The use of diary methods to study new questions in employee innovation. Paper read at 18th Annual Australian New Zealand Academy of Management Conference (ANZAM), at Dunedin, New Zealand.

De Vliert, E. 1997. Complex Interpersonal Conflict Behavior: Theoretical Frontiers. Hove, UK.: Psychology Press. Yin, R. K. . 2003. Case Study Research: Design and Methods. Thousand Oaks, Ca: Sage.

Zalan, T. , and G. Lewis. 2004. Writing about methods in qualitative research: Towards a more transparent approach. In R. Marschan-Piekkari and C. Welch (Edt.) Handbook of Qualitative Research Methods for International Business. Cheltenham: Edward Elgar. 